\title{
Ketangguhan Pribadi Orang tua Tunggal : Studi Kasus pada Perempuan Pasca Kematian Suami
}

\author{
Dara Nurfitri ${ }^{1}$ E Siti Waringah ${ }^{2}$ \\ Fakultas Psikologi Universitas Gadjah Mada
}

\begin{abstract}
Losing a husband due to death causes feelings of griefs and raises some problems. It changes the status of women became a single parent. The aims of this study are to understand what causes single parents to own hardiness and how the hardiness is able to help them rise from the critical period after their husband died. This study uses a qualitative method with a case study research. Informants are three single parents and three significant others. This study uses an in-depth semi-structured interview for data collection. The results show that the three informants were able to rise above the critical period after their husband died and survived as a single parent until now. This happens because all the informants have hardiness. The effort and time required for the informants to rise are different. Three factors that gave contribution to increasing hardiness are mastery experiences, feelings of positivity, and parental explanatory styles. In the other hand, the researcher found another factor that categorized as internal and external factors.
\end{abstract}

Keywords: critical period; hardiness; single parent; rise

Abstrak. Kehilangan suami karena kematian menimbulkan perasaan duka cita, memunculkan beberapa permasalahan, dan mengubah status perempuan menjadi orang tua tunggal. Penelitian ini bertujuan untuk memahami apa yang menyebabkan para perempuan orang tua tunggal dapat memiliki ketangguhan pribadi dan bagaimana ketangguhan pribadi yang dimiliki tersebut mampu membantunya bangkit dari masa kritis setelah suami meninggal. Metode penelitian yang digunakan adalah pendekatan kualitatif studi kasus. Informan dalam penelitian berjumlah tiga orang tua tunggal dan tiga significant other. Teknik pengumpulan data dalam penelitian dilakukan dengan cara wawancara mendalam semi terstruktur. Hasil penelitian menunjukkan bahwa ketiga informan mampu bangkit melewati masa-masa kritis setelah sang suami meninggal dan bertahan menjadi orang tua tunggal sampai saat ini. Hal tersebut terjadi karena ketiganya memiliki ketangguhan pribadi. Usaha dan waktu yang dibutuhkan informan untuk bangkit berbedabeda. Tiga dimensi ketangguhan pribadi, yakni komitmen, kontrol, dan tantangan ditemukan dalam diri ketiga informan.

Kata kunci: bangkit; ketangguhan; orang tua tunggal

Perjalanan menjadi orang tua tidak kan anak dengan baik dan menjaga semudah yang dibayangkan. Membesar- keutuhan keluarga adalah tanggung

\footnotetext{
${ }^{1}$ Korespondensi mengenai isi artikel ini dapat

dilakukan melalui daranurfitri@gmail.com

${ }^{2}$ Atau melalui sitiwaringah@gmail.com 
jawab para orang tua dalam sebuah keluarga. Namun, dalam kehidupan nyata, sering dijumpai kondisi di mana salah satu orang tua tidak lagi hadir dalam keluarga. Hal tersebut membuat tanggung jawab yang seharusnya dipikul bersama justru harus dipikul oleh salah satu pihak saja. Keadaan tersebut mengubah status orang tua menjadi single parent atau orang tua tunggal. Hurlock (1994) menyatakan bahwa single parent adalah orang tua tunggal (mungkin ibu, mungkin ayah) yang bertanggung jawab atas anak setelah kematian pasangannya, perceraian, atau karena kelahiran anak di luar pernikahan.

Fokus dalam penelitian ini adalah perempuan atau ibu sebagai orang tua tunggal atau single mother. Perempuan disebut sebagai orang tua tunggal apabila dirinya sudah tidak lagi hidup bersama suami dan pengasuhan anak seluruhnya menjadi tanggung jawabnya sendiri (Aprilia, 2013). Menurut Qaimi, single mother adalah suatu keadaan di mana seorang ibu menduduki dua jabatan sekaligus, sebagai ibu yang merupakan jabatan alamiah dan juga sebagai ayah (Akmalia, 2012).

Kematian merupakan salah satu realita dalam kehidupan yang tidak dapat dihindari. Kematian didefinisikan sebagai berhentinya semua fungsi vital tubuh termasuk detak jantung, aktivitas otak (termasuk batang otak), dan pernapasan (Sing, 2005). Kehilangan seseorang karena kematian selalu meninggalkan kesedihan yang mendalam, apalagi jika orang tersebut adalah pasangan hidup. Kehilangan seseorang yang dicintai, akan menyebabkan seorang individu merasakan sakit yang begitu dalam, frustrasi, serta membutuhkan waktu yang cukup lama untuk kembali normal (Papalia, 2002).

Kematian suami membuat perempuan menjadi orang yang bertanggung jawab terhadap kelanjutan hidup keluarganya (Pranandari, 2011). Sebuah survei yang dilakukan oleh Badan Koordinasi Keluarga Berencana (BKKBN) pada tahun 2004 di Indonesia dan diperoleh hasil data yang menunjukkan bahwa ada sekitar 40 juta keluarga yang berkepala rumah tangga dengan status janda. Data tahun 2011 juga menyebutkan, bahwa jumlah perempuan Indonesia yang menjadi kepala rumah tangga mencapai tujuh juta orang (http://poskotanews.com /2012/05/16/7-juta-perempuan-indonesiajadi-orang tua-tunggal/ diakses pada tanggal 16 Januari 2016).

Peristiwa kehilangan pasangan menjadi awal bagi perempuan untuk menjadi orang tua tunggal dalam kehidupan selanjutnya. Menjalani peran sebagai orang tua tunggal berarti mengalami perubahan yang dapat menimbulkan beberapa permasalahan, sebab seseorang yang semula berperan hanya sebagai ibu, harus berperan juga sebagai ayah (Perlmutter dan Hall, 1985). Perubahan tersebut mengharuskan perempuan sebagai orang tua tunggal bertanggung jawab sepenuhnya terhadap kehidupan keluarga selepas ditinggalkan sang suami. Hal tersebut diungkapkan oleh Fassinger dan McLanahan (dalam Pranandari, 2011) bahwa keharusan orang tua tunggal perempuan memenuhi semua kebutuhan keluarga, anak, serta kebutuhan dirinya sendiri membuatnya mengalami stres yang lebih besar dibandingkan dengan perempuan yang masih memiliki suami.

Bagi orang tua tunggal, satu bulan pertama menjalani hidup sendiri merupakan hal yang sangat sulit. Para orang tua tunggal cenderung mengalami resiko meningkatnya penyakit fisik dan munculnya beberapa gejala depresi, kehilangan status, kesulitan ekonomi, serta dukungan sosial yang lebih rendah (Stroebe \& 
Stroebe, dalam Cavanaugh dan Fields, 2006).

Perempuan yang menjadi orang tua tunggal dihadapkan pada permasalahan-permasalahan baru dalam hidupnya karena tanggung jawabnya menjadi lebih besar serta harus menghadapinya seorang diri. Salah satu permasalahan yang sering muncul adalah permasalahan finansial. Permasalahan finansial tersebut dapat memengaruhi well-being individu. Orang tua tunggal yang mengalami permasalahan finansial tersebut dapat mengalami depresi dan berkurangnya kepercayaan diri (Olson, DeFrain, \& Skogrand, 2010). Berdasarkan data dalam salah satu kolom berita online, jumlah perempuan Indonesia yang menjadi orang tua tunggal cukup banyak dan mayoritas hidup di bawah garis kemiskinan (http://poskotanews.com/ 2012/05/16/7juta-perempuan-indonesia-jadi-orang tuatunggal/ diakses pada tanggal 16 Januari 2016). Hal tersebut terjadi karena kebanyakan perempuan yang bekerja, tidak menghasilkan uang sebanyak lakilaki (Olson, DeFrain, \& Skogrand, 2010). Oleh karena itu, perempuan yang ditinggal pasangannya, harus memutar otak untuk menopang kehidupan ekonomi keluarga, terutama bagi para perempuan yang sebelumnya hanya mengandalkan pemasukan keuangan dari sang suami.

Permasalahan lainnya yang muncul adalah bagaimana perempuan harus dapat berperan ganda, yakni sebagai ayah dan ibu dalam mengurusi serta membesarkan anak-anaknya (Aprilia, 2013). Anak-anak membutuhkan panutan dalam hidupnya dan hal tersebut idealnya didapatkan dari kedua orang tuanya. Dalam kondisi demikian, para orang tua tunggal perempuan harus mampu menggantikan peran ayah, terutama bagi anak laki-laki, sebab anak laki-laki membutuhkan role model untuk mengembangkan diri sesuai dengan peran gendernya.

Ada juga permasalahan lain yang muncul dari segi sosial, yakni banyaknya pandangan negatif dari masyarakat terhadap status janda (Damayanti, 2015). Status janda membuat seorang perempuan sulit berbaur dengan masyarakat yang masih memandang negatif perempuan yang menyandang status tersebut. Perempuan yang menjadi orang tua tunggal merasa takut dirinya akan ditolak ketika berinteraksi dengan orang lain karena status jandanya. Padahal para perempuan tersebut membutuhkan dukungan sosial untuk bangkit dan menyelesaikan permasalahannya, namun tidak semua masyarakat bisa memaklumi status janda tersebut.

Berdasarkan data dalam beberapa tahun, diindikasikan bahwa janda lebih mengalami kecemasan daripada duda (Smith \& Zick, dalam Cavanaugh dan Fields, 2006). Tanpa menghiraukan usia, laki-laki juga lebih memiliki keuntungan jika dibandingkan dengan perempuan dalam kesempatan membentuk hubungan baru dan menikah lagi karena lingkungan sosial tidak mempermasalahkan hubungan antara laki-laki yang lebih tua dengan perempuan yang lebih muda. Berbeda dengan janda, para janda lebih sedikit menaruh perhatian untuk membangun hubungan baru dibandingkan dengan para duda. Hal tersebut diungkapkan oleh Hurlock (1994), yang menyatakan bahwa kesempatan menikah lagi pada perempuan yang berstatus janda semakin kecil sejalan dengan usia yang semakin tua.

Permasalahan lainnya dari segi sosial adalah sulitnya menghadiri acaraacara keluarga (Olson, DeFrain, \& Skogrand, 2010). Menjadi orang tua tunggal tidak semudah yang dibayang- 
kan. Tidak hanya dalam acara keluarga, acara-acara lain yang mengharuskan orang tua hadir pun terasa sulit karena sosok ayah dan ibu yang diharuskan hadir dalam sebuah acara. Hal tersebut diperparah dengan kondisi anak yang menyaksikan orang tuanya yang tidak lengkap seperti keluarga-keluarga lainnya.

Kenyataan bahwa kini sebagai orang tua tunggal harus berjuang sendiri dalam melakukan semua pekerjaan terkadang mengganggu pikiran. Pikiranpikiran aneh seperti, apakah saya bisa memenuhi kebutuhan finansial keluarga?, apakah saya sudah memilih sekolah yang tepat untuk anak?, bagaimana kalau saya tidak bisa membahagiakan anak?, bagaimana kalau anakanak terus menanyakan ayahnya?, dan masih banyak lainnya, mulai bermunculan. Jika hal tersebut berlangsung terus-menerus, maka well-being dalam diri para orang tua tunggal dapat terganggu dan dapat memunculkan perasaan inadequate (Olson, DeFrain, \& Skogrand, 2010).

Semua hal tersebut tidak dapat dibiarkan, sebab para orang tua tunggal harus bangkit dan melanjutkan hidupnya. Belum lagi tanggung jawabnya untuk terus membesarkan anak-anak dan mempertahankan fungsi keluarga yang optimal harus tetap dijalankan, walaupun sudah tidak ada sosok suami yang menemani. Namun, berjuang untuk bangkit setelah ditinggalkan pasangan bukan merupakan hal yang mudah dan membutuhkan waktu untuk berproses yang tidak sebentar.

Keberhasilan perempuan untuk bangkit dan berperan sebagai orang tua tunggal di tengah berbagai tekanan membutuhkan penyesuaian dan dukungan dari berbagai aspek. Selain itu, diperlukan juga ketangguhan pribadi dari dalam diri perempuan tersebut. Kobasa menyebut ketangguhan pribadi sebagai karakteristik kepribadian yang membuat individu menjadi lebih kuat, tahan, stabil, dan optimis dalam menghadapi stres serta mengurangi efek negatif dari peristiwa yang dihadapinya (Winda dan Sudiantara, 2014).

Perempuan dengan ketangguhan pribadi yang rendah cenderung menilai suatu peristiwa secara lebih negatif dan menunjukkan lebih banyak gejala depresi serta penyakit fisik daripada perempuan dengan ketangguhan pribadi yang tinggi (Rhodewalt \& Zone, dalam Lukey dan Tepe, 2008). Hadjam (2004) mengungkapkan hal lain, yakni bahwa ketangguhan pribadi merupakan karakteristik kepribadian yang berfungsi sebagai sumber perlawanan saat individu berhadapan pada suatu kejadian yang menimbulkan stres. Diungkapkan juga bahwa ketangguhan pribadi mampu mengurangi pengaruh kejadian-kejadian hidup yang mencekam dengan meningkatkan penggunaan strategi penyesuaian, seperti memanfaatkan sumber-sumber sosial di lingkungan sekitar untuk dijadikan tameng, motivasi, dan dukungan dalam menghadapi masalah.

Oleh karena itu, dalam menghadapi kenyataan yang disebabkan oleh meninggalnya suami, perempuan yang kehilangan orang yang dicintainya tersebut akan bertahan bila memiliki ketangguhan pribadi dalam dirinya. Ketangguhan pribadi akan membuat perempuan mampu bangkit dari masamasa kritis dan kembali menjalani hidupnya. Selain itu, permasalahanpermasalahan yang muncul pun dapat diatasi. Hal tersebut juga akan membuat perempuan sebagai orang tua tunggal mampu melanjutkan kembali perannya dalam mempertahankan fungsi keluarga dengan baik.

Fungsi penting dari keluarga adalah melakukan perawatan dan sosialisasi pada anak (Lestari, 2012). Secara umum, keberfungsian keluarga 
merujuk pada kualitas kehidupan keluarga, baik pada level sistem maupun subsistem, dan berkenaan dengan kesejahteraan, kompetensi, kekuatan, dan kelemahan keluarga (Shek, dalam Lestari, 2012). Keberfungsian keluarga dapat dinilai dari tingkat resiliency dan strength keluarga dalam menghadapi berbagai tantangan (Lestari, 2012). Perspekstif resiliency memandang distress sebagai tantangan bagi keluarga dan bukan hal yang merusak, serta melihat potensi yang dimiliki keluarga untuk tumbuh dan melakukan perbaikan. Sedangkan perspektif strength, melihat keberfungsian keluarga dari kualitas relasi di dalam keluarga yang memberikan sumbangan bagi kesehatan emosi dan kesejahteraan (well-being).

Penelitian ini bertujuan untuk memahami apa penyebab para perempuan yang menjadi orang tua tunggal dapat memiliki ketangguhan pribadi dan bagaimana ketangguhan pribadi yang dimiliki tersebut mampu membantunya bangkit dari masa kritis untuk mulai menata hidup, menjalankan tugas sebagai orang tua tunggal, dan tetap mempertahankan fungsi keluarga dengan optimal setelah sang suami meninggal.

\section{Metode}

Penelitian ini menggunakan pendekatan kualitatif. Metode penelitian kualitatif yang digunakan dalam penelitian ini adalah studi kasus. Lokasi penelitian berada di Kota Cilegon dengan pertimbangan kekhasan dalam segi religiusitas dan industri perekonomian. Informan dalam penelitian ini berjumlah tiga orang perempuan orang tua tunggal. Informan penelitian memiliki kriteria sudah menjadi orang tua tunggal dan belum menikah lagi setelah suami meninggal, memiliki anak dan bersedia menjadi narasumber.
Informan penelitian yang dipilih adalah tiga orang wanita yang telah berhasil bangkit melewati masa-masa kritis setelah suami meninggal. Peneliti menentukan kriteria informan yang memiliki anak dengan pertimbangan ketiganya akan lebih memikirkan keberlanjutan kehidupan keluarga dan mengesampingkan status perkawinannya. Peneliti juga mewawancarai tiga significant other dari masing-masing informan sebagai alat untuk melakukan cross check data dalam penelitian. Kriteria significant other antara lain mengenal informan sejak masih memiliki suami sampai setelah suaminya meninggal, mengetahui proses yang dialami informan selama mengalami masa-masa sulit dan bersedia menjadi narasumber.

Teknik pengumpulan data yang dilakukan dalam penelitian ini ialah wawancara mendalam semi terstruktur. Wawancara tersebut dipilih karena sifatnya yang lebih fleksibel, namun tetap tidak melupakan tujuan dari wawancara itu sendiri, yakni memperoleh informasi secara lebih mendalam. Peneliti melakukan wawancara sebanyak dua kali kepada informan untuk mendapatkan data yang lengkap, sehingga menjawab semua pertanyaan yang peneliti miliki. Alat bantu yang digunakan dalam wawancara adalah aplikasi sound recorder di telepon genggam untuk merekam selama proses wawancara dan sebuah pedoman wawancara yang berisi sejumlah pertanyaan terkait dengan kasus yang ingin dipahami.

Teknik analisis data yang digunakan dalam penelitian ini adalah teknik analisis tematik. Analisis diawali dengan menyusun transkrip hasil wawancara. Transkrip tersebut diketik dalam format tanya jawab yang dimasukkan dalam tabel dan diberi nomor setiap barisnya. Selanjutnya ialah membuat koding pada transkrip data. Setelah kode atau tema 
ditentukan, kemudian data disusun dan dikategorisasikan berdasarkan kode-kode yang telah diberikan. Setelah menemukan hubungan antarkategori, langkah selanjutnya adalah analisis dan interpretasi.

\section{Hasil}

Kematian dapat menimbulkan perasaan dukacita. Informan Ts merasa terkejut dan sedih saat mengetahui bahwa suaminya meninggal. Informan $\mathrm{Zu}$ merasa tidak percaya bahwa suaminya benar-benar sudah meninggal. Informan $\mathrm{Zu}$ berharap peristiwa meninggalnya sang suami adalah mimpi, lalu dengan terus mencubit-cubit tangannya informan sadar kalau peristiwa itu memang nyata. Kematian suami juga memunculkan kekhawatiran dalam diri informan $\mathrm{Zu}$ mengenai kehidupan ke depannya setelah ditinggalkan oleh sang suami. Berbeda dengan dua informan lainnya, informan Et merasa sangat sedih dengan kepergian sang suami, tetapi dirinya berusaha untuk tetap tegar.

Ketiga informan menemui beberapa permasalahan selepas sang suami meninggal. Informan Ts menghadapi beberapa permasalahan, yaitu masalah finansial, absennya figur ayah bagi ketiga anaknya, prestasi anak yang menurun, dan khawatir berlebihan saat anak sakit. Informan $\mathrm{Zu}$ menghadapi beberapa permasalahan yang berbeda, yakni masalah finansial, tugas memperbaiki bagian rumah yang bersifat maskulin (bohlam mati atau genting rumah bocor), anak-anak protes dan memberontak dalam bentuk kenakalan, anak-anak kehilangan antusias saat liburan, anak-anak minder dengan teman-temannya, melahirkan tanpa ditemani suami, serta khawatir berlebihan saat anak sakit. Informan Et menghadapi permasalahan berbeda pula, yakni masalah finansial, kehilangan sosok untuk sharing, kerepotan dalam mengawasi anak-anak, pekerjaan tertunda demi membimbing anak belajar, bingung saat menerima undangan dari sekolah untuk orang tua, anak laki-lakinya yang tidak pergi ke masjid, anak sulungnya yang memprotes keadaan, takut jika ada pencuri masuk rumah, serta khawatir berlebihan saat anak sakit.

Dibalik semua permasalahan tersebut, ketiga informan terus berusaha mencari jalan keluar dari semua permasalahannya. Ketiga informan berusaha menyelesaikan permasalahannya dengan cara yang berbeda-beda. Informan Ts mengatasi permasalahan finansialnya dengan menerima pesanan membuat kuekue basah, membantu anaknya berjualan online, dan merampingkan kebutuhannya. Informan Ts sedapat mungkin menjaga silaturahmi yang baik dengan keluarganya karena telah membantu membiayai sekolah anak-anaknya. Informan Ts meminta bantuan kakak laki-lakinya untuk bisa menjadi panutan bagi ketiga anaknya, menggantikan sosok ayah yang telah meninggal.

Informan $\mathrm{Zu}$ memperbaiki permasalahan finansialnya dengan cara berjualan barang-barang kebutuhan pokok di rumahnya dan mendaftarkan anaknya ke dalam asuransi kesehatan untuk meringankan biaya saat terapi. Untuk permasalahan praktis yang dihadapinya, informan $\mathrm{Zu}$ mengerjakan sendiri jika dirasa bisa dan baru mencari bantuan orang lain untuk mem-perbaikinya jika dirasa hal tersebut sulit diselesaikan, seperti memperbaiki genting yang bocor. Permasalahan anak-anak informan $\mathrm{Zu}$ terselesaikan dengan terus memberi pengertian kepada anak-anaknya untuk memahami kondisi keluarga dan memberi semangat dengan menceritakan kisah yang lebih buruk dari keadaan keluarga informan $\mathrm{Zu}$ saat ini. 
Informan Et memutuskan untuk bekerja lebih keras, menerima panggilan les privat, dan memulai bisnis kaos demi menambah pemasukan untuk keuangan keluarga. Informan Et juga mulai mengurangi pengeluaran, seperti tidak lagi makan-makan di luar rumah serta memanfaatkan uang asuransi yang diperoleh dari asuransi tempat suaminya bekerja. Informan Et melakukan sharing dengan saudara atau rekan kerjanya, ada pun waktu sharing-nya tergantung pada waktu luang yang dimilikinya. Informan Et dibantu oleh pembantu rumah tangganya dalam mengurusi anak dan beberapa pekerjaan rumah tangga, informan Et juga memberikan pengertian kepada anakanaknya agar ketiganya paham mengenai kondisi keluarga saat ini, terutama masalah keuangan. Informan Et melakukan pemeriksaan kesehatan rutin kepada ketiga anaknya untuk mengurangi rasa khawatirnya saat anak-anak sakit.

Masing-masing informan punya cara tersendiri untuk mengusir kesedihan selepas sang suami meninggal. Informan Ts sudah sejak awal menutupi perasaan sedihnya, terutama di depan ketiga anaknya, sebab informan Ts tidak ingin memberikan aura buruk bagi anakanaknya. Informan Ts hanya menangis pada saat beribadah dan sebisa mungkin selalu tampak ceria di hadapan anakanaknya. Informan Ts juga bergaul, mencari banyak teman agar tidak merasa kesepian dan tidak terus memikirkan peristiwa meninggalnya sang suami. Informan Ts beserta ketiga anaknya akan berziarah ke makam sang suami dan saling bercerita mengenang sosok ayah jika merasa sangat rindu dengan sang suami.

Informan $\mathrm{Zu}$ mengalami kesedihan selama dua tahun lamanya dan sempat menutup diri dari lingkungan di sekitarnya. Informan $\mathrm{Zu}$ mendengarkan banyak tausiyah dan mendapat bantuan dari ahli hipnoterapi untuk membantunya mengurangi kesedihan. Informan $\mathrm{Zu}$ mulai melupakan kesedihannya karena memfokuskan perhatiannya pada anak bungsunya yang lahir dalam keadaan cacat. Informan $\mathrm{Zu}$ mampu bangkit dari kesedihan dan bertahan menjadi orang tua tunggal demi kesembuhan anak bungsunya tersebut.

Informan Et mengalami kesedihan dan masa-masa terberatnya pada tahun pertama kematian sang suami. Informan Et sempat menutup diri selama enam bulan dan menghambat pekerjaannya. Informan Et mulai menyibukkan diri dengan pekerjaan seiring dengan berjalannya waktu. Informan Et mengungkapkan bahwa dirinya mulai bisa melupakan kesedihan sejak disibukkan dengan pekerjaannya di sekolah. Informan Et juga membaca beberapa buku dan mencari kata-kata inspiratif yang membantunya untuk menjadi lebih tegar.

Ketiga informan memiliki sumber kekuatan yang berbeda-beda. Salah satu kekuatan terbesar yang sama-sama dimiliki oleh ketiganya ialah saat melihat tumbuh kembang anak-anaknya. Masingmasing informan juga menyebutkan alasan dirinya dapat bangkit. Informan Ts mengatakan bahwa dirinya mampu bangkit karena selalu mengingat nasihat dari suaminya untuk belajar ikhlas dan tidak larut dalam kesedihan saat ditinggal mati oleh orang terdekat, selalu menyemangati diri sendiri agar tampak kuat di depan anak-anak, menerima dukungan dari keluarga dan teman-temannya, memiliki karakter yang sabar dan banyak bersyukur, serta mengingat pola asuh orang tuanya.

Informan $\mathrm{Zu}$ mengungkapkan bahwa dirinya mendapat kekuatan dari doa, dzikir, dan tausiyah. Alasan lainnya, informan $\mathrm{Zu}$ juga selalu mengingat pesan 
suaminya untuk membesarkan anakanaknya, melihat tumbuh kembang ketiga anaknya, menerima dukungan dari keluarga dan teman-temannya, memiliki pengalaman hidup susah saat kecil, dan mengingat nasihat kedua orang tuanya.

Sedangkan menurut informan Et, kekuatannya berasal dari dukungan keluarga dan teman-temannya, melihat tumbuh kembang ketiga anaknya, memiliki karakter yang penyabar, memegang teguh agama, memiliki pengalaman terbiasa jauh dari orang tua yang membuatnya menjadi mandiri, pernah merasakan peristiwa kehilangan orang terdekat juga, serta mengingat nasihat dari kedua orang tuanya.

Karakter-karakter informan saat ini, yang membuatnya mampu bangkit dari kesedihan, dipengaruhi oleh pola asuh orang tuanya dahulu. Informan Ts mengatakan bahwa orang tuanya selalu mengajarkan dirinya untuk kuat, mandiri, bertanggung jawab, dan mengenal agama dengan baik. Informan $\mathrm{Zu}$ mengungkapkan bahwa orang tuanya selalu mengajarkan untuk taat pada agama, disiplin, dan menjaga pergaulan. Tidak jauh berbeda, Informan Et juga selalu diajari untuk disiplin, sopan santun, dan menjaga ibadah.

Hilangnya sosok pemimpin dalam keluarga secara tidak langsung mengubah kondisi keluarga. Menurut informan Ts, kondisi keluarga berubah dan tidak sebaik saat suaminya masih hidup, terutama dari segi ekonomi. Lain halnya dengan informan $\mathrm{Zu}$ yang mengatakan bahwa perubahan yang terjadi adalah berkurangnya kasih sayang untuk anak-anak karena saat ini hanya diperoleh dari ibu. Sedangkan perubahan pada keluarga Et adalah hilangnya beberapa kebiasaan yang seringkali dilakukan bersama saat ayahnya anak-anak masih hidup.
Absennya sosok pemimpin dalam keluarga, tidak mengubah makna keluarga bagi ketiga informan. Sampai saat ini, semuanya masih menganggap keluarga sebagai hal yang sangat penting. Informan Ts berusaha menjaga keharmonisan keluarga dengan tetap bersabar dan selalu menyemangati anak-anaknya, menjaga keterbukaan antar anggota keluarga, dan mengusahakan quality time bersama anakanaknya. Informan $\mathrm{Zu}$ berusaha menjaga keharmonisan keluarga dengan terus memberikan kasih sayang dan pendidikan untuk ketiga anaknya serta menjaga kekompakkan dengan semua anggota keluarga. Informan Et berusaha menjaga keharmonisan keluarga dengan cara menjaga komunikasi, menjunjung keterbukaan antar anggota keluarga, dan mengusahakan quality time bersama anakanaknya.

Menjalani masa-masa kritis setelah suami meninggal, membuat para informan mengalami perubahan dalam dirinya. Informan Ts mengungkapkan bahwa dirinya berubah menjadi pribadi yang tegas, tegar, mandiri, dan lebih bersabar. Informan $\mathrm{Zu}$ juga berubah menjadi pribadi yang lebih mandiri dan mampu menjadi sosok pemimpin dalam rumah, menggantikan sang suami. Tidak jauh berbeda, informan Et pun berubah menjadi pribadi yang lebih mandiri, lebih kuat, dan lebih sibuk karena harus mengurusi semuanya seorang diri.

Ketiga informan memiliki harapan untuk dirinya sendiri dan untuk anakanaknya. Segala hambatan dan permasalahan segera diatasi oleh ketiganya demi mencapai harapannya tersebut. Informan Ts memiliki harapan untuk tetap kuat dan bisa menjalani hari-hari ke depannya dengan baik bersama ketiga anaknya. Informan Ts juga berharap agar anakanaknya bisa berprestasi dan terus terbuka dengan dirinya. Informan Ts berusaha 
untuk selalu tegar dan menyemangati ketiga anaknya agar harapannya tersebut benar-benar dapat terwujud.

Informan $\mathrm{Zu}$ berharap agar dirinya terus diberi kekuatan dan kesehatan sehingga dapat terus menyemangati dan membesarkan anak-anaknya sampai sukses. Informan $\mathrm{Zu}$ juga berharap anakanaknya bisa mendapat pendidikan sampai kuliah dan menjadi mandiri. Agar semua harapannya tercapai, terutama harapan bagi anak-anaknya, informan $\mathrm{Zu}$ selalu berusaha memberikan semangat kepada anak-anaknya.

Informan Et berharap agar dirinya dapat lebih mandiri, kuat, mawas diri, dan tetap tegar. Informan Et pun berharap agar anak-anaknya bisa menjadi lebih mandiri dan mengerti kondisi keluarga yang sudah berubah. Agar harapannya tersebut dapat tercapai dan keadaan keluarga menjadi lebih baik, informan Et berusaha untuk terus membimbing anakanaknya dan tetap menjaga silaturahmi yang baik dengan siapapun itu.

Ketiga informan menilai peristiwa meninggalnya sang suami secara berbeda. Informan Ts menilai peritiswa meninggalnya suami sebagai takdir yang harus dijalani. Lain halnya dengan informan $\mathrm{Zu}$ yang menilai peristiwa tersebut sebagai cobaan yang luar biasa. Informan Et sendiri menilai peristiwa meninggalnya suami sebagai suatu hal yang diterimanya dengan ikhlas dan tanpa rasa penyesalan.

Setiap peristiwa memiliki makna tersendiri bagi yang mengalaminya, begitu juga dengan ketiga informan yang ada dalam penelitian ini. Informan Ts memaknai peristiwa meninggalnya sang suami sebagai suatu hal yang membuatnya menjadi mandiri dan lebih dekat dengan Tuhan. Informan $\mathrm{Zu}$ memaknainya sebagai ujian yang hadir untuk menguatkan. Sedangkan, Informan Et memaknainya sebagai peristiwa yang membuatnya menjadi lebih mandiri.

\section{Diskusi}

Ketangguhan pribadi dikemukakan pertama kali oleh Kobasa dan merupakan karakteristik kepribadian individu yang mempunyai daya tahan terhadap stres (Allred dan Smith, 1989). Ketangguhan pribadi membantu individu untuk bertahan secara adaptif serta mengurangi dampak negatif dari kejadian yang menimbulkan stres dalam hidupnya. Ketangguhan pribadi yang dimaksud dalam penelitian ini merujuk kepada ketangguhan pribadi yang dimiliki oleh para informan penelitian, yakni orang tua tunggal yang telah ditinggal mati sang suami.

Kematian secara sederhana dapat diartikan sebagai kondisi tidak berfungsinya semua organ biologis, seperti sudah tidak bernafas, berhentinya peredaran darah, dan tubuh yang kaku (Santrock, 2012). Suami dari ketiga informan dinyatakan meninggal oleh dokter karena hasil diagnosis pun menunjukkan bahwa semua organ biologisnya sudah tidak lagi berfungsi. Kematian juga dapat menimbulkan perasaan dukacita. Menurut Santrock (2012), dukacita adalah kelumpuhan emosional, tidak percaya, kecemasan akan berpisah, putus asa, sedih, dan kesepian yang menyertai ketika individu kehilangan orang yang dicintainya. Ketiga informan merasakan beberapa perasaan yang disebutkan oleh Santrock mengenai dukacita tersebut.

Kehilangan pasangan merupakan kejadian yang menyedihkan dalam hidup dan dapat menimbulkan banyak permasalahan bagi yang ditinggalkan. Hurlock (dalam Akmalia, 2012) menjabarkan permasalahan yang dihadapi oleh perempuan yang menjadi orang tua 
tunggal, yaitu masalah ekonomi, masalah praktis, masalah psikologis, masalah pengasuhan anak, masalah keluarga, dan sulitnya memenuhi figur ayah untuk anaknya. Semua permasalahan tersebut dialami oleh ketiga informan dalam penelitian ini, namun dalam bentuk yang berbeda-beda.

Ketangguhan pribadi menurut Kobasa dan Maddi adalah karakteristik kepribadian individu yang mempunyai daya tahan terhadap stres (Allred dan Smith, 1989). Adanya ketangguhan pribadi tersebut membuat individu menjadi lebih kuat, optimis, stabil, dan tahan dalam menghadapi stres serta mengurangi efek negatif yang dihadapinya. Adanya ketangguhan pribadi itulah yang membuat ketiga informan menjadi kuat, optimis, stabil, dan tahan dalam menjalani masa-masa kritis setelah sang suami meninggal.

Ketangguhan pribadi dipercaya dapat mengurangi efek negatif stres setidaknya dengan dua cara (Kobasa dan Maddi, dalam Eaddy, 2000). Cara pertama adalah proses penilaian. Individu yang tangguh cenderung menganggap peristiwa yang menimbulkan stres sebagai suatu hal yang tidak berbahaya, melainkan bermanfaat. Ketiga informan tidak menilai peristiwa meninggalnya suami dan permasalahan yang muncul dalam hidupnya sebagai sebuah peristiwa yang buruk. Informan Ts menilai masa-masa kritis yang dihadapinya sebagai sebuah takdir dari Tuhan dan harus dijalani. Informan Ts yakin bahwa Tuhan sudah menuliskan yang terbaik untuk sang suami dan dirinya. Informan $\mathrm{Zu}$ menilai peristiwa yang dialaminya sebagai cobaan yang luar biasa untuk menguatkan dirinya. Informan Et menilai peristiwa meninggalnya suami dan semua permasalahan yang ada sebagai suatu hal yang harus diterima dengan ikhlas dan dijalani tanpa rasa penyesalan.

Cara kedua adalah efek negatif stres dikaitkan dengan perilaku koping yang digunakan. Individu dengan ketangguhan pribadi cenderung menyeleksi dan menggunakan koping yang sesuai. Menurut William, Wiebe, \& Smith (dalam Eaddy, 2000), individu dengan ketangguhan pribadi yang tinggi cenderung menggunakan transformasi koping yang tepat daripada koping regresif, seperti denial atau penolakan. Ketiga informan dalam penelitian ini menerima peristiwa meninggalnya sang suami, walaupun ada perasaan berat dalam hatinya. Ketiga informan tidak menolak kenyataan bahwa sang suami meninggal, tidak melarikan diri dari masalah, dan tidak menyalahkan diri sendiri atas peristiwa yang terjadi. Ketiganya justru berusaha sekuat mungkin untuk bertahan dan mencari jalan keluar dari semua permasalahan yang terjadi selepas sang suami meninggal.

Kobasa (dalam Bissonnette, 1998) mengungkapkan bahwa ketangguhan pribadi memiliki beberapa dimensi, yaitu komitmen, kontrol, dan tantangan. Komitmen membantu individu merasa terkait dan tertarik ke dalam suatu situasi karena dirinya yakin situasi tersebut penting untuk mencapai tujuan dan harapannya (Florian et al., dalam Stasiowski, 2008). Individu yang memiliki komitmen mempunyai tujuan atau harapan yang memungkinkan dirinya untuk menemukan dan mengidentifikasi makna dari sebuah peristiwa (Winda dan Sudiantara, 2014).

Ketiga informan merasa terikat dengan peristiwa meninggalnya sang suami dan juga semua permasalahan yang harus dihadapinya seorang diri. Ketiga informan memiliki harapan untuk dirinya 
sendiri dan untuk anak-anaknya. Segala hambatan dan permasalahan segera diatasi oleh ketiganya demi mencapai harapannya tersebut. Ketiga informan juga memaknai dengan baik peristiwa meninggalnya sang suami.

Kontrol adalah dimensi selanjutnya, individu yang kuat dalam kontrol akan selalu lebih optimis dan cenderung lebih berhasil dalam menghadapi serta menyelesaikan semua permasalahannya (Winda dan Sudiantara, 2014). Dihadapkan dengan berbagai masalah yang muncul dan harus mengatasinya sendiri, tetap membuat ketiga informan memandang hidup dengan optimis. Ketiga informan yakin bahwa semua yang terjadi dalam hidupnya sudah diatur dengan baik oleh Tuhan dan harus dijalani. Ketiganya yakin bahwa Tuhan memberikan banyak cobaan sesuai dengan kekuatan hamba-Nya, oleh karena itu ketiga informan tidak menyerah dengan keadaan. Ketiga informan juga tidak pantang menyerah mencari jalan keluar yang terbaik untuk semua permasalahannya.

Dimensi terakhir ialah tantangan. Individu yang kuat dalam tantangan percaya bahwa dirinya berhak untuk merasa nyaman dan aman. Pengalaman negatif maupun pengalaman positif dijadikan pelajaran untuk terus tumbuh dan melakukan perubahan (Kobasa dan Maddi, dalam Bissonnette, 1998). Individu tersebut tidak akan merasa terancam dengan adanya perubahan yang terjadi dalam hidupnya. Semua informan dalam penelitian ini tidak merasa terancam sedikit pun dengan perubahan yang terjadi, walaupun perubahan tersebut disebabkan karena peristiwa meninggalnya sang suami.

Bissonnette (1998) mengungkapkan bahwa ada beberapa faktor yang mempengaruhi ketangguhan pribadi, yaitu penguasaan pengalaman, perasaan yang positif, dan pola asuh orang tua. Ketiga informan dalam penelitian ini dapat memiliki ketangguhan pribadi dalam dirinya dilatarbelakangi oleh ketiga faktor tersebut. Peneliti menemukan beberapa hal yang dapat meningkatkan ketangguhan pribadi ketiga informan selain tiga faktor yang telah dijelaskan sebelumnya. Beberapa faktor temuan baru tersebut dikelompokkan menjadi faktor internal dan faktor eksternal. Faktor internal berisi karakteristik yang dimiliki oleh ketiga informan seperti sabar, banyak bersyukur, dan berpegang teguh pada agama. Faktor eksternal terdiri dari melihat tumbuh kembang anak-anak, mengingat pesan dari sang suami, serta menerima dukungan dari keluarga dan teman-teman. Dukungan yang diberikan di antaranya berupa motivasi, nasihat, doa, dan materiil.

Olson, DeFrain, \& Skogrand (2010) mendefinisikan perkawinan sebagai sebuah komitmen emosional dan legal dari dua orang yang berbagi keintiman emosional dan fisik, berbagai tugas, dan sumber-sumber ekonomi. Menurut Pasal 38 Undang-Undang Perkawinan, perkawinan dapat putus dikarenakan tiga hal, yaitu kematian, perceraian, dan atas keputusan pengadilan. Ketiga informan telah berada dalam ikatan perkawinan dengan sang suami dalam kurun waktu yang cukup lama. Namun, status perkawinan ketiga informan dengan sang suami sudah berakhir karena kematian sang suami. Oleh karena itu, ketiga informan harus bertahan demi bertanggung jawab atas seluruh tugas harian dalam kehidupan termasuk tugas-tugas yang awalnya dilakukan bersama-sama dengan pasangan. Tujuan ketiga informan bertahan adalah untuk melanjutkan kehidupan keluarga yang dimilikinya dari ikatan perkawinannya dengan sang suami. 
Keberfungsian keluarga dapat dinilai dari tingkat resiliency dan strength keluarga dalam menghadapi berbagai tantangan (Lestari, 2012). Perspekstif resiliency memandang distress sebagai tantangan bagi keluarga, bukan hal yang merusak, serta melihat potensi yang dimiliki keluarga untuk tumbuh dan melakukan perbaikan. Perspektif strength melihat keberfungsian keluarga dari kualitas relasi di dalam keluarga yang memberikan sumbangan bagi kesehatan emosi dan kesejahteraan (well-being).

Keluarga ketiga informan berfungsi dengan baik dalam menghadapi berbagai tantangan, terutama setelah peristiwa meninggalnya sang kepala keluarga. Melihat dari perspektif resiliency, semua permasalahan yang dihadapi oleh keluarga ketiga informan tidak membuat hubungan keluarga ketiganya merenggang. Masa-masa kritis yang dihadapi keluarga justru semakin memperkuat hubungan keluarga informan. Ketiga informan menjadi lebih dekat dan kompak dengan anak-anak sehingga dapat bersama-sama melakukan perubahan untuk terus melakukan perbaikan kehidupan keluarga ke depannya. Menurut perspektif strength, keluarga ketiga informan ini memiliki kualitas relasi yang baik. Ketiga informan dan anak-anaknya saling memberikan dukungan dan kasih sayang serta berusaha memenuhi setiap kebutuhan yang diperlukan sehingga membuat semuanya selalu sehat dari segi emosi dan bisa mencapai kesejahteraan. Sampai akhirnya ketiga informan mampu beradaptasi menjadi orang tua tunggal demi menjaga keutuhan keluarganya tersebut.

\section{Kesimpulan}

Peristiwa meninggalnya suami menimbulkan perasaan dukacita bagi yang ditinggalkan, terutama bagi sang istri. Status dan kehidupan yang berubah setelah sang suami meninggal, menimbulkan beberapa permasalahan yang harus dihadapi. Permasalahan yang seringkali ditemui perempuan sebagai orang tua tunggal adalah permasalahan finansial, permasalahan praktis, permasalahan psikologis, permasalahan pengasuhan anak, permasalahan keluarga, dan sulitnya memenuhi figur ayah. Menghadapi peristiwa dan permasalahan tersebut tidak semudah yang dibayangkan, membutuhkan usaha dan waktu yang berbedabeda untuk masing-masing individu.

Ketangguhan pribadi dalam diri orang tua tunggal mengambil peran penting dalam proses untuk bangkit dari keterpurukan. Ketangguhan pribadi dalam diri orang tua tunggal berfungsi dengan baik terutama dalam hal membantu dalam proses beradaptasi setelah sang suami meninggal, mengurangi akibat buruk dari stres karena mendapatkan tekanan dari berbagai permasalahan yang dihadapi, mengurangi penilaian negatif terhadap suatu peristiwa atau keadaan yang dirasa mengancam dan meningkatkan pengharapan untuk melakukan koping yang berhasil, meningkatkan ketahanan diri terhadap stres, serta membantu individu untuk melihat kesempatan sebagai suatu latihan untuk mengambil keputusan.

Ketangguhan pribadi memiliki tiga dimensi yang membantu para orang tua tunggal untuk bangkit dari masa-masa kritis setelah sang suami meninggal. Tiga dimensi ketangguhan pribadi itu adalah komitmen, kontrol, dan tantangan. Ketangguhan pribadi yang dimiliki orang tua tunggal tersebut dilatarbelakangi oleh beberapa faktor, yakni penguasaan pengalaman, perasaan yang positif, dan pola asuh orang tua. Selain ketiga faktor tersebut, terdapat pula beberapa faktor temuan 
yang dikelompokkan menjadi faktor internal dan eksternal. Faktor internal terdiri dari karakteristik dalam diri informan seperti penyabar, banyak bersyukur, dan memegang teguh agama. Faktor eksternal terdiri dari melihat tumbuh kembang anak, mengingat pesan atau nasihat dari sang suami, serta memperoleh dukungan dari keluarga dan teman-teman. Dukungan dari keluarga dan teman-teman dapat berupa nasihat, semangat, dan materiil.

Hilangnya sosok pemimpin keluarga tidak mengubah makna keluarga bagi orang tua tunggal. Walaupun status perkawinan yang dimiliki sudah berakhir, namun para orang tua tunggal tetap memilih untuk bertahan demi meneruskan hidup bersama keluarganya. Orang tua tunggal berusaha melakukan berbagai cara demi menjaga keutuhan dan keharmonisan keluarga, sehingga keluarga dapat berfungsi sebagaimana mestinya. Beberapa cara yang dapat dilakukan adalah berusaha untuk terus bersabar, memberikan kasih sayang dan pendidikan untuk anak-anak, bersikap terbuka dan menjaga komunikasi yang baik dengan anak-anak, menjaga kekompakkan dan menyemangati anak-anak, serta tetap melakukan kegiatan berkualitas bersamasama.

\section{Saran}

Peneliti menyarankan agar penelitian selanjutnya menambahkan kriteria informan yaitu waktu lamanya sang suami meninggal. Hal tersebut dilakukan agar peneliti memperoleh gambaran apakah ketangguhan pribadi yang dimiliki oleh informan tersebut tetap bertahan, berkurang, atau justru semakin baik. Peneliti juga menyarankan untuk meneliti orang tua tunggal yang tidak memiliki ketangguhan pribadi untuk mengetahui apa yang menyebabkan hal tersebut terjadi dan apa yang membedakannya dengan para orang tua tunggal yang berhasil bangkit karena memiliki ketangguhan pribadi. Peneliti selanjutnya diharapkan dapat menggali informasi lebih dalam kepada significant others. Sehingga dukungan informasi yang diperoleh pun menjadi akurat dan sangat membantu dalam proses triangulasi data.

\section{Daftar Pustaka}

Akmalia. (2013). Pengelolaan stres pada ibu single parent. EMPHATHY Jurnal Fakultas Psikologi, 2(1), 1-22.

Allred, K. D., \& Smith, T. W. (1989). The hardy personality: Cognitive and physiological responses to evaluative threat. Journal of Personality and Social Psychology, 56(2), 257-266.

Aprilia, W. (2013). Resiliensi dan dukungan sosial pada orang tua tunggal (Studi kasus pada ibu tunggal di Samarinda). eJurnal Psikologi, 1(3), 268-279.

Bissonnette, M. (1998). Optimism, hardiness, and resiliency: A review of the literature prepared for the child and family partnership project. Diunduh dari http://citeseerx.ist.psu.edu/ viewdoc/summary?doi=10.1.1.468. 5846

Cavanaugh, J. C. \& Fields, F. B. (2006). Adult development and aging, 5th edition. Thomson Learning, Inc.

Damayanti, S. D. (2015). Pengatasan masalah istri pasca kematian suami (Studi fenomenologi deskriptif). (Disertasi: tidak dipublikasikan). Universitas Islam Negeri Sultan Syarif Kasim Riau.

Eaddy, S. L. (2000). An exploration of the relationship between hardiness and resilience for people impacted by HIV. 
(Disertasi: tidak dipublikasikan). School Of Texas Woman's University. Us.

Hadjam, R. (2004). Peran kepribadian tahan banting pada gangguan somatisasi. Anima, Indonesian Psychological Journal, 19(2), 122-135.

Hurlock, E. B., (1994). A life span approach: 5th Edition. Jakarta: Erlangga.

Lestari, S. (2012). Psikologi keluarga. Penanganan nilai dan penanganan konflik dalam keluarga. Jakarta: Kencana Prenada Media Group.

Lukey, B. J. \& Tepe, V. (2008). Biobehavioral resilience to stress. CRC Press, Inc.

Olson, D., DeFrain, J., \& Skogrand, L. (2010). Marriages and families: Intimacy, diversity, and strengths. New York: McGraw Hill.

Papalia, D. (2002). Human development. (8th Ed). New York: Mc Graw Hill.

Perlmutter, M. \& Hall, E. (1985). Adult development and aging. New York: John Willey \& Sons.

Pranandari, K. (2011). Kecerdasan adversitas ditinjau dari pengatasan masalah berbasis permasalahan dan emosi pada orang tua tunggal wanita. Jurnal Ilmiah Psikologi, 1(2), 121-128.

Poskota News. (2012). Karena berbagai alasan 7 juta perempuan indonesia jadi orangtua tunggal. Diunduh dari http://poskotanews.com/ 2012/05/16/7-juta-perempuanindonesia-jadi-orang tua-tunggal , diakses pada Sabtu, 16 Juli 2016, pukul 08.45 WIB

Santrock, J. W. (2012). Life-span development. New York: The McGraw-Hill Companies Inc.

Sing, A. (2005). Death \& dying. Indian Journal of Social Psychiatry, 1-18.

Stasiowski, S. A., (2008). Optimism and hardiness: Influence on coping and psychological distress. (Disertasi: tidak dipublikasikan) Long Island University: US.

Winda, A., \& Sudiantara, Y. (2014). Hardiness pada wanita penderita kanker payudara. Psikodimensia, 13(2), 1-13. doi: 10.24167/psiko.v13i2.260 